\title{
Economic Analysis of Households and Education Levels of Parents on the Decision to Continue to College Education at SMK Siang, Tulungagung District
}

\author{
Nursalim Bayu Mu'arif \\ Universitas Bhineka PGRI Tulungagung \\ Narfik Umurul Hadi \\ Universitas Bhineka PGRI Tulungagung
}

\begin{abstract}
This research is motivated by the still low number of students who continue their studies to higher education in Tulungagung, Indonesia. This can be seen in the attitude of students who do not show interest in the compilation of high school choices presented by the teachers. The purpose of this article is threefold. First, this article aims to elucidate how the level income of household economics is related to the decision to enroll in higher education. The second research objective is to find whether the parental level of education has an impact on the decision to continue in higher education. Third, this study aims to understand whether the combined influence of household economic level and parental level of education influences the decision of studying higher education. This paper relies on questionnaires conducted in the class X SMK SIANG Tulungagung during the academic year 2019/20 as a method of data collection. The data analysis techniques include validity, reliability, classic assumption tests, multiple linear regression and hypothesis testing. The results of the data analysis show that: (1) the value of $\mathrm{t}$ arithmetic in the variable (Xl) 'analysis of the household economic' of $2.148<\mathrm{t}$ table are 2.004. Thus, it can be concluded that there are significant differences in how the household economic level influences the decision to go to college. (2) The value of $t$ arithmetic on the variable (X2) 'level of parental education' of 2,200>t table is 2,006. 3) The test results obtained through calculating the F value of 4.970> from F table are 3.16.
\end{abstract}

Keywords: Household Economics, Parental Education, Higher Education

\section{INTRODUCTION}

Education is a process of preparing individuals to be able to adapt to the ever-changing globalization era. In order to not leave students behind, public education institutions are being increasingly demanded to provide high-quality education. In this case, the government has a big responsibility for building quality human capacity and one way to do so is through education. According to research Nike, education is one way to build quality human capacity which in turn is essential to achieve national development goals.

Nowadays, societies are changing rapidly and so is the field of education. Education is essential for the development of every human being and it is highly influential to one's life prospects and family relations. Furthermore, good quality of education is key to the nationstate as it forms strong and knowledgeable individuals. ${ }^{2}$ Likewise, family and education cannot be separated as both have advantages and complementary features. For instance, households often rely on educated members that provide for the family. Formal education is an academic path structured in different levels: basic education (SD), secondary education (SMP \& SMA / SMK), and higher education.

There are many factors that influence a parent's decision to continue their child's studies to college. ${ }^{3}$ Based on a survey at SMK Siang, Tulungagung Regency, one factor could

1 Suciningrum, Nike Pratiwi. 2015. "pengaruh status sosial ekonomi orang tua dan motivasi belajar tehadap minat melanjutkan studi ke perguruan tinggi pada kelas xi di sma pusaka l jakarta”. Jakarta : UNNES

2 Cipta. Djaali. (2008). Psikologi Pendidikan. Jakarta: Bumi Aksara.

3 Fitriani, Khoerunisa. 2014. "Pengaruh Motivasi, Prestasi Belajar, Status Sosial Ekonomi Orang Tua dan Lingkungan 
be students' interest in learning, which in some occasions is still low. This can be seen through the weak student response to teaching and learning activities in the classroom. This lack of enthusiasm from the student side can be seen especially in subjects they do not like. Achieve your dreams by trying and praying continuously. This research paper is motivated by the background information and research findings presented above.

\section{METHODOLOGY}

This study aims to determine whether the household economic level and level parental education have an effect on the decision to continue to tertiary education. The population in this study were all 55 students of class X SMK Siang Tulungagung Regency.

This research paper relies on non-experimental research design, in which the researcher does not control or manipulate data, but rather directly collects primary data. To determine the population sample, this research paper relied on sampling techniques used in the existing literature. ${ }^{4}$ As a result, this study used an 'all population technique' which is a method that takes into consideration all subjects whose number is less than 100. Namely, a population study. The variables in this study were measured using a semantic differential scale. In this study, data collection was taken from a questionnaire filled in by class X SMK Siang Kab. Tulungagung during the even semester of the 2019/2020 academic year.

The variables used in this study are household economic level $\left(\mathrm{X}_{1}\right)$, the parental education level $\left(\mathrm{X}_{2}\right)$, and the decision to continue to Higher Education (Y). Sugiyono ${ }^{5}$ states that:

"Scale Likert is used to measure a person's attitudes, opinions, and perceptions about social phenomena. In research, this social phenomenon has been specifically determined by researchers, hereinafter referred to as research variables. With a Scale Likert, the variables to be measured are translated into variable indicators. Then these indicators are used as a starting point for arranging instrument items which can be in the form of statements or questions. The answer to each instrument item that uses a Scale Likert has a gradient from very positive to very negative, which can be in the form of words."

The instrument used in this study was a questionnaire which was developed and compiled in the form of statement items based on existing theories regarding household economic variables, parental education level, and the decision to continue to college.

\section{A. 'Household Economic' Variables}

In the question items, there are several alternative answers using a Scale Likert. Sugiyono ${ }^{6}$ states that the Scale Likert uses a 5-level scale according to the alternative answers which consist of the following:

Table 3.4. Description of 'Household Economic' Variable Scale Likert

\footnotetext{
Sekolah terhadap Minat Melanjutkan ke Perguruan Tinggi pada Siswa Kelas XII Akutansi SMK Negeri 1 Kendal". Dalam Economic Education Analysis Journal 3 (1) (2014). Semarang: UNNES.

4 Sugiyono. 2011. Statistika untuk Penelitian. Bandung : Alfabeta.
}

5 Ibid

6 Ibid 
16 | Economic Analysis of Households and Education Levels of Parents on the Decision to Continue to College Education at SMK Siang, Tulungagung District

\begin{tabular}{|c|c|c|}
\hline No & Explanation & Score \\
\hline 1 & Score for answer A. & 5 \\
\hline 2 & Score for answer B & 4 \\
\hline 3 & Score for answer C & 3 \\
\hline 4 & Score for answer D & 2 \\
\hline 5 & Score for answer E & 1 \\
\hline
\end{tabular}

The total ideal score (criterion) for household economic items $=10 \times 5=50$ (if all answered A) and the lowest score is $10 \times 1=10$. Following the description above, the interval length can be calculated by the formula: ${ }^{7}$

$i=\frac{R}{K}=\frac{50-10}{5}=\frac{40}{5}=8$

Information:

$\mathrm{i}=$ Class Intervals

$\mathrm{R}=$ Range

$\mathrm{K}=$ Number of Classes

Table 3.5 Value Range of 'Household Economic' Variable Scale Likert

\begin{tabular}{|c|c|}
\hline $\begin{array}{c}\text { Vulnerable to } \\
\text { Value }\end{array}$ & Criteria \\
\hline $42-50$ & Option A \\
\hline $34-41$ & Option B \\
\hline $26-33$ & Option C \\
\hline $18-25$ & Option D \\
\hline $10-17$ & Option E \\
\hline
\end{tabular}

According to table 3.5, if the respondent's value is in the value range between 10-17 the value criterion is Option E. In turn, if the respondent's value range is between $18-25$, the criteria for the value obtained is Option D. For the value range 26-33, the criteria for the value obtained is Option C, for the range of values between 34-41 the criterion the value obtained is Option B and the top value range between 42-50 is obtained if the answer is Option A.

\section{B. 'Parental Education Level' Variable}

In the question items, there are several alternative answers using a Scale Likert. Sugiyono ${ }^{8}$ states that the Likert scale uses a 5-level scale according to the alternative answers consisting of the following:

The total ideal score (criterion) for the item of parental education level = $10 \times 5=50$ (if all answer to Option A) and the lowest score is $50 \times 1=50$. Following the description above, the interval length can be calculated by the formula:

$i=\frac{R}{K}=\frac{50-10}{5}=\frac{40}{5}=8$

Information:

7 Ibid

8 Ibid 
$\mathrm{i}=$ Class Intervals

$\mathrm{R}=$ Range

$\mathrm{K}=$ Number of Classes (Sugiyono, 2011).

Table 3.7 Value Range of the Scale Likert Variable of 'Parental Education Level'

\begin{tabular}{|c|c|}
\hline Vulnerable to Value & Criteria \\
\hline $42-50$ & Option A \\
\hline $34-41$ & Option B \\
\hline $26-33$ & Option C \\
\hline $18-25$ & Option D \\
\hline $10-17$ & Option E \\
\hline
\end{tabular}

According to the table 3.7, if the respondent's value is in the value range between 10 17 , the value criterion is Option $\mathrm{E}$, while if the respondent's value range is between $18-25$, the criteria for the value obtained is Option D. In the value range 26-33, the criteria for the value obtained is Option C and in the range of values between 34-41, the criteria for Option B are obtained. Finally, in the range of top values, namely between 42-50, the value criterion is Option A.

\begin{tabular}{|c|c|c|}
\hline No & Explanation & Score \\
\hline 1 & Score for answer A. & 5 \\
\hline 2 & Score for answer B & 4 \\
\hline 3 & Score for answer C & 3 \\
\hline 4 & Score for answer D & 2 \\
\hline 5 & Score for answer E & 1 \\
\hline
\end{tabular}

C. Variable 'Decision to Continue to Higher Education'

In the question items, there are several alternative answers using a Scale Likert. Sugiyono ${ }^{9}$ states that the Likert scale uses a 5-level scale according to the alternative answers consisting of the following:

The total ideal score (criterion) for the decision item to continue to college $=10 \times 5=$ 50 (if all answer SS) and the lowest score is $10 \times 1=10$. Following the description above, the interval length can be calculated by the formula:

$i=\frac{R}{K}=\frac{50-10}{5}=\frac{40}{5}=8$

Information:

$\mathrm{i}$ = Class Intervals

$\mathrm{R}=$ Range

$\mathrm{K}=$ Number of Classes

Table 3.9 Value Range of the Scale Likert for the 'Decision to Continue to Higher Education'

9 Ibid 
18 | Economic Analysis of Households and Education Levels of Parents on the Decision to Continue to College Education at SMK Siang, Tulungagung District

\begin{tabular}{|c|c|}
\hline Value Range & Criteria \\
\hline $42-50$ & Strongly Agree (SS) \\
\hline $34-41$ & Agree (S) \\
\hline $26-33$ & Doubt (RG) \\
\hline $18-25$ & Disagree (TS) \\
\hline $10-17$ & Strongly Disagree (STS) \\
\hline
\end{tabular}

According to the table 3.9, if the respondent's value is in the range of values between 10-17, the criteria for the value is Strongly Disagree (STS) while if the respondent's value range is between 18-25 then the criteria for the value obtained is Disagree (TS). In the value range $26-33$, the criteria for the value obtained is Doubt $(R G)$ and in the range of values between 34-41, the criteria for the value of Agree (S) are obtained. Finally, in the top value range, namely between 42-50, the criteria for the value of Strongly Agree (SS) are obtained.

\section{Test Instrument Requirements}

Test instruments - validity and reliability tests - are necessary to obtain good questionnaire data from each variable: $\mathrm{X}_{1}$ (household economic level), $\mathrm{X}_{2}$ (parental education level), and Y (the decision to continue to higher education).

The test rule used in this research paper is the following:

a) If the count value $\mathrm{r} \geq$ from $\mathrm{r}$ table, the questionnaire item is declared valid and can be used as a data collection tool.

b) If the calculated value $\mathrm{r} \leq$ from $\mathrm{r}$ table, the questionnaire item is declared invalid and cannot be used as a data collection tool.

\section{DATA ANALYSIS}

From the results of the multiple linear regression test - which can be seen under the 'Coefficients' table - we obtain the following equation $\mathrm{Y}=\mathrm{a}+\mathrm{b}_{1} \mathrm{X}_{1}+\mathrm{b}_{2} \mathrm{x}_{2} \cdot{ }^{10}$ Namely, $\mathrm{Y}=10,363$ $+0,259 \mathrm{X}_{1}+0,515 \mathrm{X}_{2}$. The explanation for this equation is as follows:

1. (a) is a constant of 10.363 , which states that if the independent variables (household economy and parental education level) are 0 (zero), then the value of the dependent variable for the decision to go to college is 10.363 .

2. $\left(b_{1}\right)$ represents the regression coefficient of $X_{1}$. The regression coefficient 0.259 states that assuming $X_{2}$ is constant, one unit increase in variable $X_{1}$ results in an increase in the amount of $Y$ of 0.259 .

3. ( $\left.b_{2}\right)$ represents the regression coefficient of $X_{2}$. The regression coefficient of 0.515 states that each additional unit increase in the variable $X_{2}$ results in an increase in the amount of $Y$ of 0.515 , assuming the variable $X_{1}$ is constant.

Furthermore, in the multiple linear regression test, we can see that two independent variables - household economy $\left(\mathrm{X}_{1}\right)$ and parental education level $\left(\mathrm{X}_{2}\right)$ - have an influence towards the decision to continue to higher education $(Y)$. The test results are obtained through the SPSS version 21 for Windows. 


\section{OUTCOME}

In this study, researchers found that there was a positive and significant effect of household economic analysis and the level of parental education on the decision to continue to tertiary education at SMK SIANG Tulungagung. With a household economic level of less than Rp. 1.5000.000, this research shows that 28 students (50.91\%) answered Option A (incapable category), 27 students (49.09\%) answered option B (the moderate category), 0 students (0\%) answered option C (sufficient category), 0 students (0\%) answered Option D (good category), and 0 students ( $0 \%$ ) answered option $\mathrm{E}$ (very good category).

This research was conducted at SMK Siang Tulungagung during the academic year 2019/2020 to measure the impact of household economics and the level of parental education towards the decision to continue to higher education. The conclusions obtained from the analysis are the following:

1. There is a significant effect of household economic analysis on the decision to continue to higher education.

2. There is a significant influence of the level of parental education on the decision to continue to higher education.

3. There is a significant effect of household economic analysis and the level of parental education on the decision to continue to higher education.

\section{RECOMMENDATION}

In accordance with the aforementioned conclusions, the researchers would like to suggest the following recommendations.

\section{A. Recommendations for teachers}

A teacher should provide insightful advice, support and attention to motivate and increase students' interest in continuing onto higher education. In addition, teachers should establish good channels for communication with students. It is also necessary for teachers to maintain good communication with students' parents so that teachers can still have control over the condition of students outside the school environment.

\section{B. Recommendations for parents}

While the average economic condition in this class is classified as middle to low, parents should pay close attention to the communication with teachers so that students are more active and enthusiastic about learning.

\section{Recommendations for students}

As a new generation of citizens, students should continue with their academic studies and increase their interest in learning. This is key for students to achieve their dreams and to be a model to follow by future generations.

\section{REFERENCES}

Ahmadi, Abu. 2003.Psikologi Umum. Jakarta : Rineka Cipta.

Arikunto, Suharsimi. 2010. Prosedur Penelitian Suatu Pendekatan Praktik. Jakarta: Rineka

Baharuddin dan Esa Nur wahyuni. 2008. Teori Belajar \& Pembelajaran. Yogyakarta:Ar-Ruzz Media. Baharuddin. 2012. Psikologi Pendidikan Refleksi Teoritis terhadap Fenomena. Yogyakarta: Ar-Ruzz Media.

Bandura, Albert.1986. Self Efficacy: Toward a unifying Theory of Behavioral Change, Psychological 
20 | Economic Analysis of Households and Education Levels of Parents on the Decision to Continue to College Education at SMK Siang, Tulungagung District

Review. Journal. Stanford University: Lawrence Erlbaum Associate, Incll7-148.

Cipta. Astaria, Tita. 2006. Hubungan Antara Self Efficacy dengan Minat Melanjutkan Studi ke Perguruan Tinggi pada Siswa SMA Negeri 2 Ciamis. Skripsi. Yogyakarta: Universitas Ahmad Dahlan.

Cipta. Djaali. (2008). Psikologi Pendidikan. Jakarta: Bumi Aksara.

Dalyono. 2005. Psikologi Pendidikan. Jakarta: Rineka

Djaali. 2012 .Psikologi Pendidikan. Jakarta: Rineka Cipta.

Fatmawati, siti. 2019. "Minat Siswa-Siswi UntukMelanjutkan Studi KePerguruan Tinggi Ditinjau Dari

Tingkat Pendidikan Orang Tua Di Man 1 Kota Tangerang Selatan”. Jakarta : UNNES

Fitriani, Khoerunisa. 2014. "Pengaruh Motivasi, Prestasi Belajar, Status Sosial Ekonomi Orang Tua dan Lingkungan Sekolah terhadap Minat Melanjutkan ke Perguruan Tinggi pada Siswa Kelas XII Akutansi SMKNegeri 1 Kendal". Dalam Economic Education Analysis Journal 3 (1) (2014). Semarang: UNNES.

Ghozali, Imam. 2011. Aplikasi Analisis Multivariate dengan Program IBM SPSS 19. Semarang: Badan Penerbit Universitas Diponegoro.

Ghufron, M. Nur, dan Rini Risnaita S. 2014. Teori-teori Psikologi. Jogjakarta: ArRuzz Media.

Hurlock, Elizabeth B. 2006. Psikologi Perkembangan. Jakarta : Erlangga.

Ihsan, Fuad. 2003. Dasar-dasar Pendidikan. Jakarta : Rineka Cipta.

Mahmud, Dimyati. 2009. Psikologi Pendidikan. Jakarta : Departemen Pendidikan dan Kebudayaan.

Nasution, Syafrina dan Tarigan, Lemta. 2013. "Pengaruh Sosial Ekonomi Orang Tua terhadap Minat Anak Melanjutkan Pendidikan ke Perguruan Tinggi (Studi Kasus Kelas XI Semester Genap di SMA Sinar Husni Medan Hel Vetia Kabupaten Deli Serdang Tahun Ajaran 2010/2011”. Dalam Jurnal Citizenship Vol.00 No.00 2013.Medan: Universitas Negeri Medan.

Slameto. 2003. Belajar dan faktor-faktor yang mempengaruhinya. Jakarta: Rineka Cipta.

Suciningrum, Nike Pratiwi. 2015. "pengaruh status sosial ekonomi orang tua dan motivasi belajar tehadap minat melanjutkan studi ke perguruan tinggi pada kelas xi di sma pusaka 1 jakarta". Jakarta : UNNES

Sugiyono. 2011. Statistika untuk Penelitian. Bandung : Alfabeta. 